\section{KEY POINTS}

- Agriculture is an important sector in economies of the Central Asia Regional Economic Cooperation (CAREC) Program, which makes effective sanitary and phytosanitary (SPS) measures a priority.

- Modernizing SPS is part of the regional agenda, but the adoption of global standards varies among CAREC countries.

- The coronavirus disease or COVID-19 pandemic has heightened the need and demonstrated the potential for e-certificates to make agriculture trade safer and more efficient.

- International systems are in place to help countries adopt electronic SPS certification.

- The opportunity for digitalization is strengthening and CAREC members are well-placed to adopt electronic phytosanitary certificates (ePhyto).

- Efforts toward adopting the ePhyto Solution should be sustainable and coordinated with broader trade facilitation initiatives.

- Upgrading, capacity building, and regional cooperation are essential.

\title{
Expanding Agri-Trade in Central Asia through the Use of Electronic Certificates
}

\author{
Dorothea Lazaro \\ Regional Cooperation Specialist \\ Public Management, Financial Sector \\ and Regional Cooperation Division \\ East Asia Department \\ Asian Development Bank
}

Ghulam Samad

Senior Research Officer

CAREC Institute

\author{
Loreli de Dios \\ Consultant
}

Asian Development Bank

\author{
Aiken Rose Tafgar \\ Consultant \\ Asian Development Bank
}

This brief describes the readiness of the members of the Central Asia Regional Economic Cooperation (CAREC) Program to use electronic certificates, particularly electronic phytosanitary certificates (ePhyto) developed by the International Plant Protection Convention (IPPC). ' The use of IPPC's ePhyto Solution reflects the thrust to facilitate trade through digital innovation and supports the CAREC agenda to modernize sanitary and phytosanitary (SPS) measures for safer trade. The brief presents the outcomes of an Asian Development Bank (ADB) and CAREC Institute survey on laws, procedures, and the use of information and communication technology (ICT) in CAREC countries to implement electronic phytosanitary certification.

This brief was jointly prepared by the Asian Development Bank and CAREC Institute. Iskandar Abdullaev, Qaisar Abbas, Robert Black, Umida Haqnazar, David McKellar, and Julius Irving Santos provided technical contributions. The brief benefited from survey inputs of CAREC countries, particularly the national plant protection organizations, and comments from the CAREC Secretariat team in ADB, and Pablo Jenkins from the Standards and Trade Development Facility in the World Trade Organization (WTO) Secretariat. Emma Fan, Director, Public Management, Financial Sector, and Regional Cooperation Division, ADB and Syed Shakeel Shah, Director, CAREC Institute, provided overall guidance. The brief is supported by the knowledge and support technical assistance (TA) for Modernizing Sanitary and Phytosanitary Measures to Facilitate Trade (TA 9500), which is cofinanced by the Regional Cooperation and Integration Fund and the People's Republic of China (PRC) Poverty Reduction and Regional Cooperation Fund.
ISBN 978-92-9262-984-7 (print) ISBN 978-92-9262-985-4 (electronic) ISSN 2071-7202 (print) ISSN 2218-2675 (electronic) Publication Stock No. BRF210288-2 DOI: http://dx.doi.org/10.22617/BRF210288-2 


\section{AGRICULTURE TRADE DEPENDS ON PRODUCTS BEING SAFE}

\section{Agriculture is an important sector in the CAREC economies,} both in terms of output and employment. Agriculture accounted for $14.2 \%$ of gross domestic product (GDP) across CAREC members in 2019, compared with the $4 \%$ global average. Agriculture comprised at least one-fifth of GDP in Afghanistan, Pakistan, and Uzbekistan. The agriculture sector also contributed $33.5 \%$ of employment in CAREC members, higher than the $27 \%$ globally. On average, agricultural commodities make up about $10 \%$ of CAREC exports - and up to $85 \%$ for Afghanistan, $28 \%$ for Georgia, and 22\% for Pakistan (Table 1).

\section{CAREC members have a broad and solid base on which} to expand and build new agricultural production, exports, and export markets. CAREC-10 members, i.e., excluding the People's Republic of China (PRC), accounted for about $1 \%$ of global GDP in 2019, but they made large contributions to global production of major agricultural commodities. ${ }^{2}$ Wheat, fruit and vegetables, cotton, oilseeds, live animals, meat, milk, and animal hides led the way. About the same group of CAREC-10 products accounted for notable portions of overall global agricultural exports (Table 2). The variety and volume of the crops and animals raised, processed, and exported are clear indications of untapped potential for scaling up CAREC's agricultural exports. Facilitating agricultural trade will contribute to CAREC countries' export diversification and sustainable growth.

\section{Agriculture faces a growing challenge in meeting many of our most essential needs, while being exposed to emerging} risks. These needs - from food to raw materials to energy - are expanding across the globe as populations and incomes rise, lifestyles change, and consumption explodes. Responding to this demand in a sustainable way has become more complex. The climate is changing, resources are dwindling, and agriculture faces more intense competition for land and water every year. Global trade in plants and animals has exposed agriculture, and the basic supplies it produces, to threats from the transnational spread of pests and diseases they can transport. Even shocks to human health and socioeconomic consequences such as from the coronavirus disease (COVID-19) pandemic have placed the spotlight on the importance of managing and minimizing these risks. As concerns on sustainability and increased vulnerabilities due to movement of goods and people escalate, there is a need to strengthen resilience against transboundary pests and disease and link SPS measures with green recovery.

\section{Table 1: Contributions of Agriculture to CAREC Economies, 2019}

\begin{tabular}{|c|c|c|c|}
\hline Economy & $\begin{array}{l}\text { Share of } \\
\text { Agriculture, } \\
\text { Forestry, and } \\
\text { Fishing Value } \\
\text { Added } \\
\text { in GDP } \\
(\%)\end{array}$ & $\begin{array}{c}\text { Share of } \\
\text { Agriculture in } \\
\text { Employment } \\
(\%)\end{array}$ & $\begin{array}{c}\text { Share of } \\
\text { Agriculture in } \\
\text { Export Value } \\
(\%)\end{array}$ \\
\hline Afghanistan & 25.8 & 42.8 & 84.9 \\
\hline Azerbaijan & 5.7 & 35.9 & 4.6 \\
\hline Georgia & 6.5 & 41.8 & 28.2 \\
\hline Kazakhstan & 4.5 & 15.8 & 5.9 \\
\hline Kyrgyz Republic & 12.1 & 21.2 & 14.7 \\
\hline Mongolia & 10.8 & 27.4 & 6.5 \\
\hline Pakistan & 22.0 & 36.7 & 22.4 \\
\hline Tajikistan & $19.2^{\mathrm{a}}$ & 44.9 & 15.6 \\
\hline Turkmenistan & $9.3^{\mathrm{b}}$ & 19.9 & 1.1 \\
\hline Uzbekistan & 25.5 & 23.9 & 13.5 \\
\hline $\begin{array}{l}\text { CAREC-10 } \\
\text { (average) }\end{array}$ & 15.0 & 33.5 & 10.0 \\
\hline PRC & 7.1 & 25.4 & 3.1 \\
\hline IMAR & 10.8 & 41.8 & 14.5 \\
\hline XUAR & $14.3^{c}$ & $36.4^{c}$ & $2.1^{c, d}$ \\
\hline $\begin{array}{l}\text { CAREC } \\
\text { economies } \\
\text { (average) }\end{array}$ & 14.2 & 33.5 & 9.4 \\
\hline
\end{tabular}

CAREC $=$ Central Asia Regional Economic Cooperation, IMAR = Inner Mongolia Autonomous Region, GDP = gross domestic product, $\mathrm{PRC}=$ People's Republic of China, XUAR = Xinjiang Uygur Autonomous Region.

a 2018.

b 2015.

c 2017.

d Includes only the four top agriculture exports for which data were available.

Notes: Year of data is 2019, except as otherwise indicated. CAREC-10 is weighted average and excludes data for the PRC. CAREC economies is weighted average for CAREC-10 together with the PRC's IMAR and XUAR regions. Averages for CAREC-10 and CAREC economies are weighted by total GDP, total employment, and total exports. Agricultural commodities are defined to be Sections 0, 1, 2 (except 27 and 28), and 4 of the Standard International Trade Classification. See chapter 8 in World Trade Organization. 2018. World Trade Statistical Review 2018. https://www.wto.org/english/res_e/ statis_e/wts2018_e/wts2018_e.pdf.

Sources: World Bank. Agriculture, Forestry, and Fishing, Value Added (\% of GDP). World Development Indicators. http://data.worldbank.org/indicator/ NV.AGR.TOTL.ZS (accessed 9 January 2021); World Bank. Employment in Agriculture (\% of Total Employment). World Development Indicators. http://data.worldbank.org/indicator/SL.AGR.EMPL.ZS (accessed 9 January 2021); International Trade Centre. Trade Map. Trademap.org (accessed 9 January 2021); China Statistics Press. 2020. Inner Mongolia Statistical Yearbook 2020; China Statistics Press. 2018. Xinjiang Statistical Yearbook 2018.

2 CAREC countries include Afghanistan, Azerbaijan, the PRC, Georgia, Kazakhstan, the Kyrgyz Republic, Mongolia, Pakistan, Tajikistan, Turkmenistan, and Uzbekistan. In this brief, CAREC-10 excludes the PRC. The share of CAREC-10 in global GDP ranged from 0.69 to 0.93 during 2008-2018. World Bank. GDP (Current US\$). World Development Indicators. https://data.worldbank.org/indicator/NY.GDP.MKTP.CD (accessed 9 January 2021). 
Table 2: Shares of CAREC-10 Countries in Top Agricultural Production and Exports, 2018

\begin{tabular}{|c|c|c|c|c|}
\hline Products & \multicolumn{2}{|r|}{$\begin{array}{c}\text { CAREC- } \\
10 \text { 's Share } \\
\text { in Global } \\
\text { Production } \\
(\%)\end{array}$} & \multicolumn{2}{|r|}{$\begin{array}{l}\text { CAREC- } \\
10 \text { 's Share } \\
\text { in Global } \\
\text { Exports } \\
(\%)\end{array}$} \\
\hline \multicolumn{5}{|c|}{ Plants and Plant Products } \\
\hline Cereals & Barley (4.1), buckwheat (2.8), wheat (7.2) & 2.9 & $\begin{array}{l}\text { Barley (4.9), buckwheat (4.1), cereal flour ( } 3.4) \text {, } \\
\text { wheat flour (20.8), milled rice (10.5), } \\
\text { wheat (4.2) }\end{array}$ & 3.5 \\
\hline Fruit & $\begin{array}{l}\text { Apples (3.4); apricots (20.4); berries, n.e.s. } \\
\text { (6.4); cherries ( } 7.6) ; \text { sour cherries (6.3); dates } \\
\text { (5.5); grapes (4.6); mangoes, mangosteens, } \\
\text { and guavas (4.2); melons (4.8); persimmons } \\
\text { (4.9); plums and sloes (2.5); quinces (16.5); } \\
\text { watermelons (5.3) }\end{array}$ & 2.8 & $\begin{array}{l}\text { Apricots (15.5), apricots, dry (37.0), cherries } \\
\text { (10.1), dates (10.3), figs, dried (7.6), grapes } \\
\text { (7.6), mangoes, mangosteen, and guavas } \\
\text { (3.5), melons (4.8), peaches, nectarines (4.8), } \\
\text { persimmons (40.8), plums and sloes (5.8), } \\
\text { plums, dried (12.9), raisins (16.8), citrus (8.1) }\end{array}$ & 2.6 \\
\hline Pulses & Beans, dry (2.2), lentils (4.2), pulses n.e.s. (5.1) & 2.1 & Beans, dry (7.5), lentils (5.5) & 3.6 \\
\hline Roots and tubers & Potatoes (4.3), roots tubers n.e.s. (5.0) & 3.5 & Potatoes (7.0) & 4.4 \\
\hline Spices & $\begin{array}{l}\text { Chilies and peppers, dry (3.8), } \\
\text { spices n.e.s. (2.9) }\end{array}$ & 2.1 & $\begin{array}{l}\text { Anise, badian, fennel, coriander (2.3), chilies } \\
\text { and peppers, dry (2.3), spices, n.e.s. (3.1) }\end{array}$ & 1.5 \\
\hline Sugar; honey & Sugar cane (3.5) & 3.2 & Molasses (2.9), refined sugar (4.7) & 2.2 \\
\hline Tree nuts & Almonds (2.6), hazel nuts (9.1) & 2.2 & Almonds (3.2), hazelnuts (11.5) & 2.0 \\
\hline Vegetables & $\begin{array}{l}\text { Cabbages (2.7), carrots and turnips (9.9), } \\
\text { cucumbers and gherkins ( } 2.7) \text {, leeks, other } \\
\text { alliaceous vegetables (4.5), onions, dry (6.0), } \\
\text { tomatoes ( } 2.9)\end{array}$ & 2.3 & $\begin{array}{l}\text { Cabbages, other brassicas (6.1), carrots, } \\
\text { turnips ( } 2.7) \text {, cucumbers, gherkins ( } 3.3) \text {, } \\
\text { eggplants (2.6), onions, dry ( } 7.5) \text {, } \\
\text { tomatoes (6.1), vegetables, fresh, n.e.s. (6.0) }\end{array}$ & 4.0 \\
\hline $\begin{array}{l}\text { Fiber crops; } \\
\text { cocoons; silk }\end{array}$ & $\begin{array}{l}\text { Seed cotton (12.3), cotton lint (12.1), } \\
\text { silkworm cocoons ( } 3.2)\end{array}$ & 11.7 & $\begin{array}{l}\text { Cotton lint (4.2), cotton linter (9.5), cotton } \\
\text { waste (14.7), silkworm cocoons, unreelable } \\
\text { (13.5), silkworm cocoons, reelable (8.5), } \\
\text { silk, raw (9.3) }\end{array}$ & 4.5 \\
\hline $\begin{array}{l}\text { Oil crops; Oil } \\
\text { seeds (exports) }\end{array}$ & $\begin{array}{l}\text { Linseed (29.5), mustard seed (6.4), } \\
\text { oilseeds n.e.s. (12.8), safflower seed (37.4), } \\
\text { cottonseed (13.1) }\end{array}$ & 1.3 & $\begin{array}{l}\text { Linseed (25.0), mustard seed ( } 4.8) \text {, sesame } \\
\text { seed (3.0), sunflower seed (5.6) }\end{array}$ & 0.6 \\
\hline \multicolumn{5}{|c|}{ Animals and Animal Products } \\
\hline $\begin{array}{l}\text { Cattle and } \\
\text { buffaloes }\end{array}$ & Buffaloes (18.9), cattle (5.7) & 7.3 & Cattle (1.5) & 1.5 \\
\hline Poultry birds & Chickens (3.0) & 2.8 & & 0.7 \\
\hline Sheep and goats & Goats (11.6), sheep (11.6) & 11.6 & Sheep (1.2) & 1.5 \\
\hline $\begin{array}{l}\text { Asses, horses, } \\
\text { mules }\end{array}$ & Asses (14.2), horses (14.0), mules (2.5) & 13.2 & Asses (74.5) & 6.6 \\
\hline Beehives & & 2.2 & & 1.6 \\
\hline Meat and offal & $\begin{array}{l}\text { Meat: buffalo (22.3), camel (3.8), } \\
\text { cattle ( } 4.6) \text {, goat ( } 8.6) \text {, horse ( } 26.9) \text {, } \\
\text { sheep (11.3) }\end{array}$ & 2.5 & $\begin{array}{l}\text { Meat: cattle (2.4), goat ( } 4.9) \text {, horse } \\
(23.0) \text {, sheep (1.4) }\end{array}$ & 0.4 \\
\hline Milk, whole fresh & $\begin{array}{l}\text { Cow's milk (6.1), goat's milk ( } 6.7) \text {, } \\
\text { sheep's milk ( } 4.4)\end{array}$ & 8.5 & & 0.6 \\
\hline Hides, skins, wool & $\begin{array}{l}\text { Buffalo hide (15.1), cattle hide (4.6), } \\
\text { goat skin (10.0), sheep skin (10.0), } \\
\text { wool, greasy (11.1) }\end{array}$ & 7.3 & $\begin{array}{l}\text { Sheep skin, dry salted (4.8), cattle hide, } \\
\text { wet salted (1.4), hides n.e.s. (1.6), wool, } \\
\text { degreased (12.8), wool, hair waste (7.6) }\end{array}$ & 2.2 \\
\hline
\end{tabular}

CAREC = Central Asia Regional Economic Cooperation, n.e.s. $=$ not elsewhere specified.

Note: The CAREC-10 countries include all the members of the program except the Inner Mongolia and Xinjiang Uygur Autonomous Regions of the People's Republic of China, due to unavailability of data.

Source: Food and Agriculture Organization of the United Nations. FAOStat. www.fao.org/faostat/en (accessed September 2020). 


\section{MODERNIZING SANITARY AND PHYTOSANITARY MEASURES IN CAREC}

\section{Modernizing SPS measures is part of the regional agenda.} However, the adoption of global standards varies among CAREC countries. The CAREC Program recognizes the importance of strong and effective SPS measures in realizing this vast potential through deeper engagement in global trade. The CAREC Integrated Trade Agenda 2030, endorsed by CAREC members in 2018, incorporates the Common Agenda for Modernization of Sanitary and Phytosanitary Measures for Trade formulated in 2015. ${ }^{3}$ This underscores the priority accorded by CAREC members to the World Trade Organization (WTO) Agreement on the Application of SPS Measures (SPS Agreement) and the Trade Facilitation Agreement. ${ }^{4}$ In 2019, a regional SPS working group for CAREC was established to spearhead policy dialogues and regional cooperation initiatives to modernize SPS systems for trade in the region and beyond.

\section{The WTO's SPS Agreement recognizes countries' rights to} protect human, animal, or plant life or health but provides that control, inspection, and approval procedures do not create unnecessary disruptions to trade and additional costs. SPS measures are to be applied only to the extent justifiable for protection and must be based on scientific principles and an assessment of risk. Alignment with international standards recognized by the WTO SPS Agreement promotes harmonization-facilitating and ensuring safer trade in agricultural products. These include the standards set and processes recommended under the International Plant Protection Convention (IPPC), World Organisation for Animal Health, or by the Codex Alimentarius Commission.

\section{CAREC countries need to accelerate the upgrading of their} national SPS systems. While legislation in some countries provides for the adoption of international standards or principles, some implementing rules and regulations are unclear, insufficient, or uncoordinated. In the case of plant health laws, secondary legislation to implement the IPPC's International Standards for Phytosanitary Measures (ISPMs) would be essential. Only a few countries in the CAREC region have accurate listing and maintain a database on plant pests present in their countries that may pose risks. This is often due to a lack of expertise in pest risk analysis and pest surveillance. There is a need to develop riskbased phytosanitary import requirements and improve control, inspection, and diagnostic capacities, including through the use of technology. ${ }^{5}$ Furthermore, when the importing country enforces SPS requirements on an agricultural commodity, the exporting country needs to provide a certificate attesting that the consignment complies with the regulations of the importing country. For instance, a phytosanitary certificate confirms the safety of the consignment, stating that specified quarantine pests were not found after inspection, testing, or treatment. The acceptability of such a certificate depends on its compliance with ISPMs.

International standards and models guide national plant protection organizations (NPPOs), the agencies that ISPM 7 prescribes are responsible for establishing phytosanitary certification systems for plants and plant products. Ten CAREC members are contracting parties to the IPPC. ${ }^{6}$ Article $V$ of the IPPC provides certification guidelines. Under the ISPMs, certificates are required for regulated articles only. ${ }^{7}$ The ISPMs that the IPPC governing body began adopting as far back as 1993 cover multiple aspects of the certification process. ${ }^{8}$ ISPM 1 requires the certification process to respect the principles of transparency, nondiscrimination, necessity, and technical justification; ISPM 7 identifies the components of a certification system; ISPM 12 lists requirements for issuing phytosanitary certificates; ISPM 20 describes the structure and operation of a phytosanitary import regulatory system; and ISPM 23 outlines the procedures for inspection of consignments. The NPPOs have sole authority for phytosanitary certification. ${ }^{9}$ Using the IPPC's model phytosanitary certificate facilitates safe, fast and smooth flow of plants and plant products.

\section{ELECTRONIC CERTIFICATION}

Electronic certification offers a step up over paper-based ones. Information and communication technology enhances transparent and uniform certification, which is crucial to a smooth, expedited

3 ADB. 2019. CAREC Integrated Trade Agenda 2030 and Rolling Strategic Action Plan 2018-2020. https://www.adb.org/documents/carec-trade-agenda2030-action-plan-2018-2020; CAREC. 2019. CAREC Common Agenda for Modernization of SPS Measures for Trade. https://www.carecprogram. org/?publication=carec-common-agenda-modernization-sps-measures-trade.

4 WTO. Trade Facilitation. https://www.wto.org/english/tratop_e/tradfa_e/tradfa_e.htm; WTO. The WTO Agreement on the Application of Sanitary and Phytosanitary Measures (SPS Agreement). https://www.wto.org/english/tratop_e/sps_e/spsagr_e.htm. Eight CAREC countries are WTO members: Afghanistan, the PRC, Georgia, Kazakhstan, the Kyrgyz Republic, Mongolia, Pakistan, and Tajikistan.

5 For a comprehensive assessment on regulation, laboratory capacity, and border services management, including details on plant protection and phytosanitary laws in CAREC countries, see ADB. 2019. Modernizing Sanitary and Phytosanitary Measures in CAREC: An Assessment and the Way Forward. https://www.adb.org/sites/default/files/publication/506151/modernizing-sanitary-phytosanitary-carec.pdf.

6 Afghanistan, Azerbaijan, the PRC, Georgia, Kazakhstan, the Kyrgyz Republic, Mongolia, Pakistan, Tajikistan, and Uzbekistan.

7 Any plant, plant product, storage place, packaging, conveyance, container, soil and any other organism, object or material capable of harboring or spreading pests, is deemed to require phytosanitary measures, particularly when international transportation is involved.

8 The ISPMs may be accessed at the Food and Agriculture Organization of the United Nations (FAO). Adopted Standards (ISPMs). https://www.ippc.int/en/coreactivities/standards-setting/ispms/.

9 Certificates are valid only if their information is complete, correct, and consistent with the model phytosanitary certificate and are dated, signed, stamped, sealed, or completed electronically by the NPPO of the exporting country. 
exchange of regulatory documents in trade. Electronic SPS systems have advantages in efficiency and security over paper-based ones. Efficiency is gained through electronic transmission of certificates, real-time validation, advance notification that facilitates timely inspections as needed, and swift communication with users. Electronic certification also promotes integrity and minimizes the risk of irregularities and fraud. Gains in security include the consistency in information that an ICT system provides through its central registry, along with data encryption.

\section{Digitized SPS systems reinforce effective phytosanitary} measures. When used in concert with international standards like the ISPMs, such a system not only strengthens border controls, monitoring, and surveillance, but it also builds trust between trading nations and confidence in each other's SPS systems. The electronic phytosanitary certificate (ePhyto) is defined by ISPM 12 as the electronic equivalent of the wording and data of phytosanitary certificate in paper form. It includes the certifying statement that the regulated plant or plant product meets the phytosanitary import requirements of the importing country, as transmitted by secure electronic means from the NPPO of the exporting country to the importing country. Digitally certified cargoes of plants and plant products are less likely to be delayed or denied entry outright due to noncompliance than those using paper documents. Digitized SPS systems also strengthen traceability in supply chains, which is a powerful tool in reducing the risk of the spread of pests and diseases.

\section{INTERNATIONAL SYSTEMS HELP COUNTRIES ADOPT ELECTRONIC SANITARY AND PHYTOSANITARY CERTIFICATION}

\author{
Global agencies have laid the groundwork and guidelines for \\ e-certification. The United Nations Centre for Trade Facilitation \\ and Electronic Business (UN/CEFACT), which provides \\ recommendations for paperless trade information exchange, \\ developed e-Cert as a standard for the secure electronic \\ transmission of data in food safety, veterinary, or phytosanitary \\ certificates. ${ }^{10}$ The World Customs Organization's Data Model \\ offers standardized, reusable sets of data definitions and electronic
}

messages to meet the procedural needs of customs agencies controlling the movement of goods. The Economic and Social Commission for Asia and the Pacific (ESCAP) 2016 framework on cross-border paperless trade paves the way for the electronic exchange and mutual recognition of trade-related data and documents in the region. ${ }^{11}$

\section{The IPPC has developed a generic system called ePhyto Solution, which allows parties to exchange ePhytos through a single point called the Hub, whether they have e-certificate} systems or not. ${ }^{12}$ Managed by the IPPC, the ePhyto Solution has three core elements: harmonization, the Hub, and the generic ePhyto national system (GeNS). Harmonization refers to the standardized approach to format, structure, and codes in the certificate exchange process. The Hub is a central server system that facilitates the exchange of ePhytos between NPPOs of countries that have already established their own national e-certification systems. The system uses extensible markup language (XML) and prescribed rules of connection. The structure, codes, and terms in messages are strictly defined. ${ }^{13}$ The GeNS is a centralized, web-based system that enables countries to produce, send, and receive ePhytos through the Hub, even before establishing their own systems. It facilitates data entry, uses standardized codes and lists, translates for export certification, and produces ePhytos that comply with the format structure, codes, and lists of ISPM $12 .{ }^{14}$ Over 90 countries are now connected to the ePhyto system, with 53 of them exchanging approximately 80,000 ePhytos on average per month. In May 2020, the Trade Control and Expert System of the European Union (EU) was also linked with the ePhyto Hub, allowing transmission and processing of ePhytos from non-EU members to all EU Member States.

\section{Countries in the Asia and Pacific region have begun participating in the ePhyto Solution, reflecting well the thrust to facilitate trade through digital innovation. Among those} using the GeNS are Fiji in the Pacific and Sri Lanka in South Asia. Fiji is exchanging ePhytos with New Zealand, while simultaneously using paper certificates. Meanwhile, Sri Lanka is exchanging with Australia, New Zealand, and the United States, among others. The members of the Association of Southeast Asian Nations are at varying stages of participation. For example, Malaysia and the Philippines are registered, while Indonesia is testing the HuB (footnote 12).

10 There are three SPS-related electronic exchange models at various stages of development. First, the bilateral government-to-government e-Cert messaging using National Single Windows, eCustoms, or the electronic SPS certificate management system; second, the G2B2B2G or bilateral government to business to business to government model; third, the ePhyto Solution, which covers phytosanitary certificates only.

11 ESCAP. 2016. Framework Agreement on Facilitation of Cross-border Paperless Trade in Asia and the Pacific. https://www.unescap.org/resources/frameworkagreement-facilitation-cross-border-paperless-trade-asia-and-pacific. This is a United Nations treaty that aims to accelerate the digitalization of trade procedures. The text was adopted by the ESCAP in 2016. It entered into force on 20 February 2021 to signatory and acceding Parties, including the PRC and Azerbaijan.

12 FAO. The IPPC ePhyto Solution. https://www.ippc.int/en/ephyto/. See also International Plant Protection Convention Secretariat. IPPC ePhyto Solutions. https://www.ephytoexchange.org/landing/.

$13 \mathrm{XML}$ is an internationally recognized computer language that is most widely used for sharing structured information.

14 GeNS is customized for the NPPO and requires the following information about ICT capability: computer setup (hardware, operating system, web browsers, software); connectivity and access to the internet; file sharing capacity; and ICT support. See IPPC ePhyto Solutions (footnote 12). 


\section{HOW PREPARED ARE CAREC COUNTRIES TO MOVE AHEAD ON THE USE OF E-CERTIFICATES?}

\begin{abstract}
ADB and CAREC Institute conducted a survey from December 2019 to February 2020 to assess CAREC members' readiness to implement electronic phytosanitary certification particularly the ability to use the ePhyto Solution. ${ }^{15}$ The survey covered members' legal environments, current phytosanitary certification procedures, and the use of ICT relative to the requirements of ISPMs 7 and 12 and the IPPC Guide to Implementing the GeNS. So far, among CAREC members, Uzbekistan has been exchanging and the PRC has been testing the ePhyto Solution.
\end{abstract}

\section{Uzbekistan is the first CAREC member country to exchange} ePhytos under the IPPC's Hub. Shortly after joining the IPPC in January 2020, Uzbekistan participated in the ePhyto Solution in October 2020 and has since processed around 15,000 certificates with European countries through the ePhyto Hub. Advanced notification on incoming consignments, reduced risk of fake certificates, and faster deployment of personnel with appropriate expertise to inspect certain shipments are a few advantages in Uzbekistan's experience. Amid the COVID-19 pandemic, ePhyto also minimized physical contact and reduced time for inspection at the borders. However, the benefits are still limited since the major markets for Uzbekistan's plant exports, namely the PRC, Kazakhstan, and the Russian Federation, have yet to adopt ePhytos, and in certain cases, require separate agreements or additional data for electronic exchange of plant health certificates. The road map for Uzbekistan's NPPO includes the enhancement of its automated information system (e-Fitouz) from field (or farm) to exports. ${ }^{16}$

\section{The PRC is an early e-Cert adopter and has been pilot testing} its connection to the ePhyto Hub. In 2010, the PRC launched its digital SPS compliance system (then called E-CIQ) based on the UN/CEFACT data model. The e-Cert model transmits in XML, can be accessed online with hypertext transfer protocol secure (https); and allows real-time verification with 128-bit encryption and user authentication. ${ }^{17}$ Accessible in real time to its trading partners, e-Cert has proven to be an effective platform for the PRC in accelerating the transmission of certificates and ensuring their authenticity and accuracy. ${ }^{18}$ In this regard, the PRC already had a well-established electronic SPS certification system when it became one of the 10 countries that piloted the ePhyto Solution in 2018. ${ }^{19}$ Ongoing adjustments are required to ensure system compatibility between the PRC's system and ePhyto Solution such as terms of data, structure, and interface for connections. ${ }^{20}$ In 2018, the import and export inspection and quarantine of agricultural products were integrated into the General Administration of Customs of the PRC, whose system is part of the PRC's International Trade Single Window. ${ }^{21}$

\section{Legislation in CAREC Countries}

\section{Laws in CAREC countries support acceptance of electronic} data, paving the way for the exchange of ePhytos. In general, CAREC countries have laws that support the issuance and receipt of electronic data. However, they vary in terms of provisions for allowing electronic exchange and international storage of data including of electronic certificates or ePhytos. Most have legislative provisions for transferring data across borders and personal data protection, and all prohibit unauthorized computer access or use. The laws of eight countries allow recognition of phytosanitary certificates issued by other countries, with some requiring a formal agreement between countries. Since all CAREC countries (with the exception of Turkmenistan) are Contracting Parties of the IPPC, no separate mutual recognition agreement is necessary between them as with other IPPC members to exchange phytosanitary data, be it in paper or electronic format (Table 3). ${ }^{22}$

\section{Most CAREC countries have specific rules, procedures, technical information, and operational capacity for phytosanitary certification. Article 1.4 of ISPM 12 stipulates that electronic phytosanitary certificates may be used if (i) the mode of issue and transmission and level of security are acceptable to the importing country's NPPO; (ii) the information provided is consistent with the IPPC model; (iii) the purpose of certification under the IPPC is realized; and (iv) the identity of the issuing NPPO can be authenticated (footnote 8).}

Ten countries specifically require implementation of ISPM 12. Under Articles 3.2 and 3.3 of ISPM 7, phytosanitary certification should be based on official information from the importing country.

\footnotetext{
15 Survey respondents are CAREC officials from NPPOs, inspection agencies, food safety or security agencies, agriculture ministries, and customs agencies.

16 State Plant Quarantine Inspection under the Cabinet of Ministers of the Republic of Uzbekistan. Checking the Submitted Documents. https://efito.uz/checkcertificate/.

17 General Administration of Quality Supervision, Inspection and Quarantine of the PRC. 2016. SPS and Trade Facilitation in China. Presentation at the ESCAPGTI International Seminar on Trade Facilitation in North-East Asia. 13 December 2016. Incheon, Seoul.

18 P. Gao. 2015. E-cert experiences-[the People's Republic of] China's Journey. Presentation at the 2nd IPPC Global Symposium on ePhyto. 9-13 November 2015. Incheon, Seoul. https://assets.ippc.int/static/media/files/publication/en/2016/02/6_E-cert_In_CHINA.pdf.

19 The other ePhyto Hub pilot countries are Argentina, Australia, Chile, Ecuador, Kenya, the Republic of Korea, the Netherlands, New Zealand, and the United States.

20 Y. Heqin. 2018. Connecting to the Hub ePhyto in China. Presentation at the 3rd IPPC Global Symposium on ePhyto. 22-26 January 2018. Kuala Lumpur, Malaysia.

21 China International Trade Single Window. https://en.singlewindow.cn/.

22 Turkmenistan has intergovernmental agreements on plant quarantine with Azerbaijan, Iran, and Uzbekistan for mutual recognition of phytosanitary certificates.
} 
At least eight CAREC NPPOs have the lists of regulated pests and articles of their trading partners. The NPPO personnel in seven countries also have the technical information needed to effectively examine and evaluate consignments (footnote 8 ). ${ }^{23}$

\section{Table 3: Availability of Enabling Legislation and Regulations in CAREC Countries}

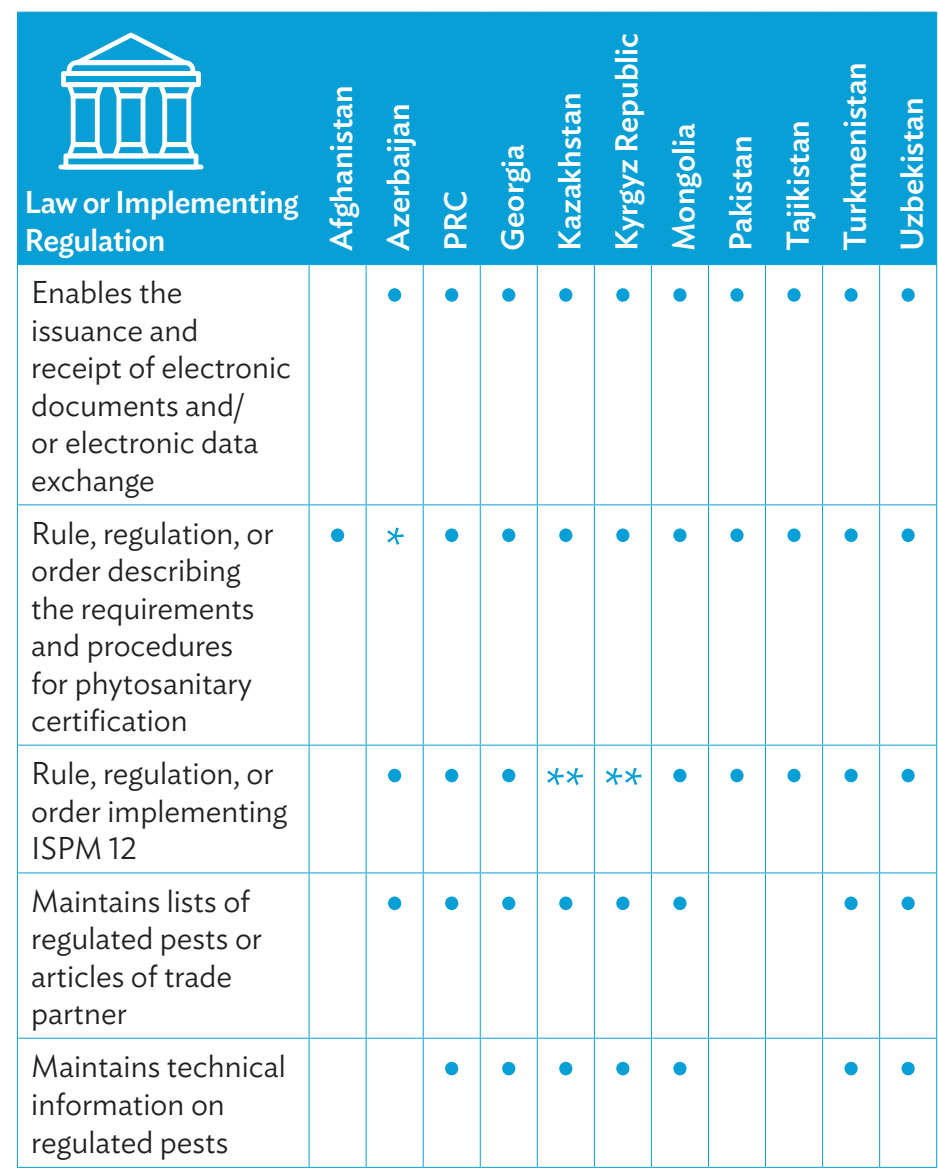

CAREC = Central Asia Regional Economic Cooperation, ISPM = International

Standards for Phytosanitary Measures, PRC = People's Republic of China.

- Specific legislation or modern statutes are reported available by the survey respondents, or known through government advice or public sources.

* After authority on issuance of export and re-export phytosanitary certificates was transferred to the Azerbaijani Food Safety Agency in 2018, the rules on issuance of phytosanitary certificates of 2006 have been repealed.

** Pursuant to the unified rules and norms for plant quarantine in the Eurasian Economic Union, approved by the Eurasian Economic Commission on 30 November 2016, No. 159.

Sources: ADB and CAREC Institute survey (as of February 2020); Food and Agriculture Organization of the United Nations. FAOLEX Database.

http://www.fao.org/faolex/country-profiles/en/ (accessed February 2021).

\section{CAREC Members' Phytosanitary Certification Procedures}

CAREC NPPOs already carry out the basic steps necessary for phytosanitary certification. All CAREC countries have established an NPPO, which carry out the following functions: (i) receive the trader's certification application; (ii) review it and the related documents against the phytosanitary import requirements of the importing country; (iii) inspect the consignment; (iv) take samples for testing, if necessary; (v) treat the consignment, if needed;

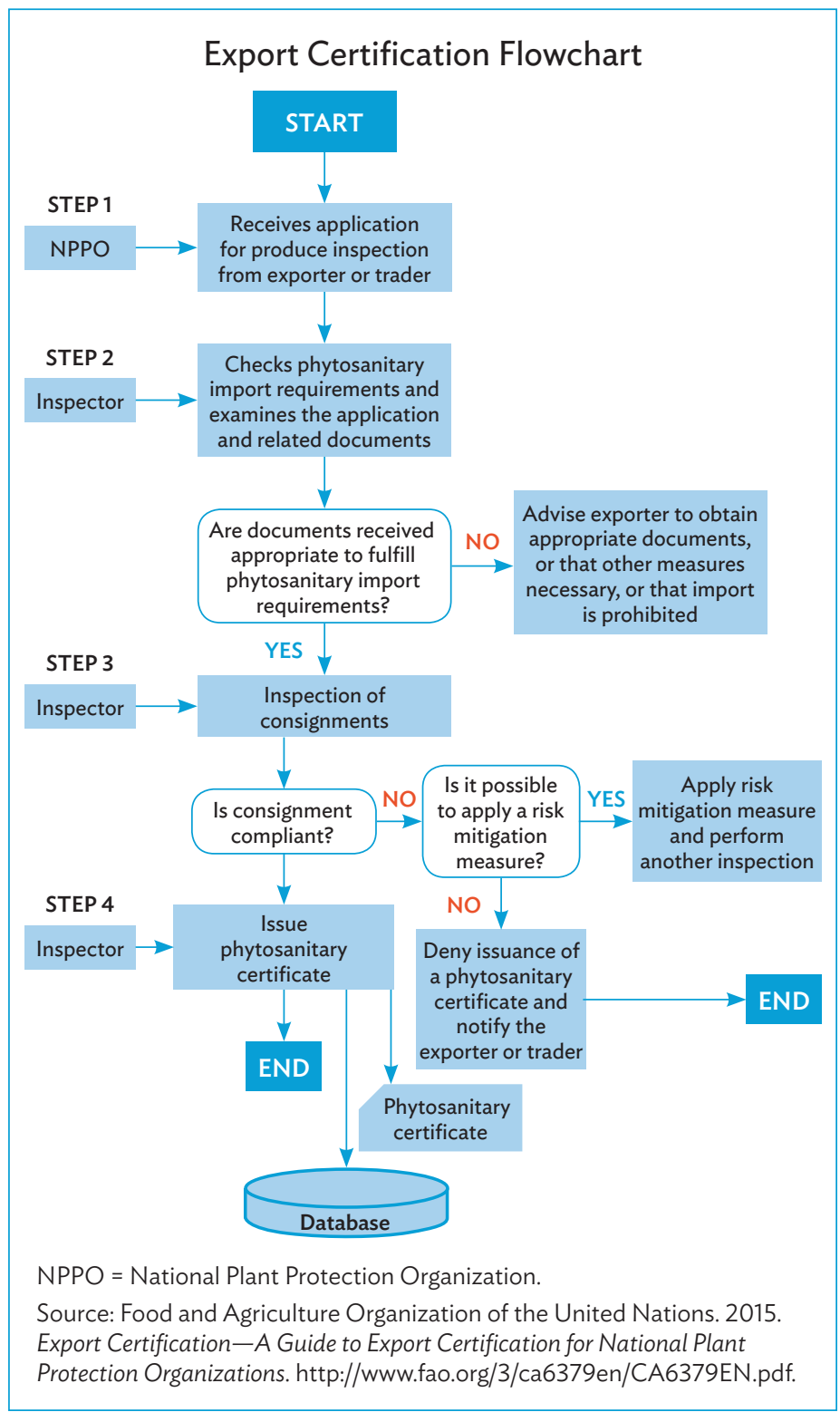

23 FAO. 2011. Phytosanitary Certification System (ISPM 7). Under ISPM 7, technical information concerning regulated pests would cover their presence and distribution within the exporting country; their biology, surveillance, detection, and identification; and the means to control them, including treatment where appropriate. 
(vi) receive payment of fees by the trader; and (vii) approve and release the certificate (see Export Certification Flowchart). Nine CAREC NPPOs meet the ISPM 7 requirement that they maintain an SPS system for documenting procedures and storing records for retrieval. These systems can be used to trace certificates and the related consignments or verify compliance with the phytosanitary import requirements of the importing country (Table 4).

\section{How long each step takes varies widely between CAREC}

NPPOs. The time it takes for an application to be filed can be as short as 10 minutes for each step to as long as 4 hours. However, the overall business process requires more time than this depending on the countries' established systems or practice, from document review for compliance, to inspection, testing of samples, or treatment, if required; up to the time of payment of fees and issuance of certificate.

In the case of the PRC, the inspection and quarantine functions for entry and exit of products have been integrated into the customs agency. Among other procedures, preregistration of importers of regulated imports is required and a directory thereof is available online. In this regard, the application requires only 1 hour, with an estimated half-day for testing and/or treatment depending on the consignment. In comparison, another CAREC member may take an hour or 3 days to review an application and its documents for compliance; an additional 3-10 days to collect and analyze the samples, and up to 14 days for treatment depending on the nature of the commodity. It takes another 2 hours to process payment, and up to 3 days to issue the certificate.

In terms of costs, fees for the application for phytosanitary certificates range from the equivalent of $\$ 0.32$ to $\$ 17.33$ per certificate, or are based on consignment volume, while two countries do not charge any fee. Paper-based certificates are still prevalent in CAREC countries, with three countries reporting use of both paper-based and electronic certificates, while one country reported that issuance of certificates is fully electronic.

\section{Most CAREC members have covered part of the distance toward full phytosanitary e-certification, but optimizing their paper processes is crucial to further progress. The WTO's Standards and Trade Development Facility (STDF) underscores effectiveness, institutional capability, and clearly defined roles and responsibility in a paper-based certification system as keys to transitioning to a successful electronic one. ${ }^{24}$ Institutional and human resources are equally important, and it is essential that phytosanitary certificates comply with ISPM 12 and NPPOs are adept with certification procedures according to ISPM 7 and how electronic transmission operates to support the migration to}

\section{Table 4: Reported Phytosanitary Certification Procedures in CAREC Countries}

\begin{tabular}{|c|c|c|c|c|c|c|c|c|c|c|c|}
\hline Procedure & $\frac{\frac{c}{d}}{\frac{d}{\frac{n}{c}}}$ & $\frac{\frac{5}{10}}{\frac{\pi}{d}}$ & $\frac{U}{\alpha}$ & 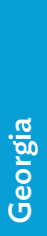 & 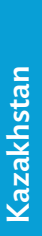 & $\frac{\frac{u}{2}}{\frac{0}{2}}$ & $\begin{array}{l}\frac{\pi}{\frac{\pi}{9}} \\
\frac{0}{0} \\
\frac{0}{2}\end{array}$ & $\frac{\frac{c}{\sqrt{n}}}{\frac{\hbar n}{\frac{n}{c}}}$ & 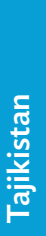 & $\frac{\frac{5}{\pi}}{\frac{n}{2}}$ & $\frac{\frac{5}{7}}{\frac{4}{\frac{5}{0}}}$ \\
\hline $\begin{array}{l}\text { Procedures cover } \\
\text { the basic steps } \\
\text { necessary for } \\
\text { phytosanitary } \\
\text { certification }\end{array}$ & • & $\bullet$ & $\bullet$ & - & - & $\bullet$ & - & • & • & $\bullet$ & $\bullet$ \\
\hline $\begin{array}{l}\text { System for } \\
\text { documenting } \\
\text { procedures and } \\
\text { maintaining records, } \\
\text { storage, and } \\
\text { retrieval }\end{array}$ & $\bullet$ & $\bullet$ & - & - & - & - & & & $\bullet$ & - & - \\
\hline $\begin{array}{l}\text { System allows } \\
\text { traceability of } \\
\text { phytosanitary } \\
\text { certificates } \\
\text { and related } \\
\text { consignments }\end{array}$ & $\bullet$ & $\bullet$ & - & - & - & - & & & • & & - \\
\hline $\begin{array}{l}\text { System allows } \\
\text { verification of } \\
\text { compliance with } \\
\text { the phytosanitary } \\
\text { import } \\
\text { requirements }\end{array}$ & - & $\bullet$ & - & & - & - & & & $\bullet$ & - & - \\
\hline $\begin{array}{l}\text { Records each } \\
\text { consignment issued } \\
\text { with phytosanitary } \\
\text { certificate }\end{array}$ & • & • & - & - & - & - & - & $\bullet$ & - & $\bullet$ & $\bullet$ \\
\hline $\begin{array}{l}\text { System of } \\
\text { documenting } \\
\text { procedures and } \\
\text { maintaining records } \\
\text { is automated }\end{array}$ & & - & • & $\bullet$ & $\bullet$ & - & & & $\bullet$ & • & - \\
\hline
\end{tabular}

CAREC $=$ Central Asia Regional Economic Cooperation, PRC = People's Republic of China.

- Rule, procedure, requirement, or system are reported available by survey respondents, or are known through government advice or public sources. Source: ADB and CAREC Institute survey (as of February 2020).

24 Standards and Trade Development Facility (STDF). Facilitating Safe Trade: Going Paperless with SPS E-certification. Briefing Note. https://www.standardsfacility. org/sites/default/files/e_Cert_Briefing_note_EN.pdf. The STDF is a global partnership working to facilitate safe trade. It grew out of a joint communiqué issued at the 2001 Doha Ministerial Conference by FAO, the World Organisation for Animal Health, the World Health Organization, the WTO, and the World Bank Group. The STDF now includes several other organizations including the International Trade Center, Organisation for Economic Co-operation and Development, United Nations Conference on Trade and Development, United Nations Industrial Development Organization, government agencies, nongovernment organizations, universities, research institutions, industry associations, and private companies. 
ePhyto. NPPOs must also have the capacity to conduct inspection based on ISPM 23 (footnote 8).

\section{Use of Information and Communication Technology by CAREC National Plant Protection Organizations}

\begin{abstract}
The alignment of CAREC NPPO ICT systems with the technical and standardized data requirements for electronic phytosanitary certification is uneven. To issue, transmit, and receive these e-certificates, ICT systems must use XML, standardized message structure and contents, standardized exchange protocols, and harmonized codes and schemes (ISPM 12). Only two NPPOs use XML, but several apply the standard terms, codes, or texts prescribed by ISPM 12 (Table 5 ). ${ }^{25}$
\end{abstract}

A minority of the NPPO systems meet other requirements in the areas of security, communications, and management. Two CAREC members use 128-bit encryption and transmit data using secure ICT mechanisms. ${ }^{26}$ Two follow UN/CEFACT-recommended standard messages to communicate the status of the exchange between countries. However, recent developments suggest that countries have improved their overall trade or government systems and upgrading of NPPOs systems is expected to follow suit. For example, Tajikistan launched its single window system for registration of export, import, and transit procedure in 2020. Similarly, Mongolia is in the process of aligning its SPS system with international standards and upgrading of its inspection management system, which will be integrated with the customs system. ${ }^{27}$

\section{RESPONDING TO COVID-19 AND BEYOND}

\section{The COVID-19 pandemic has heightened the need and} demonstrated the potential for e-certification to make trade safer and more efficient. Trade restrictions were among the key disruptions inflicted by the COVID-19 pandemic on agriculture and agricultural economies around the world in 2019-2020. ${ }^{28}$ Most countries responded to the crisis by turning inward. They moved quickly to secure domestic supplies while easing the inflow of essentials from other countries. ${ }^{29}$ This response was reflected in the CAREC region's plant agriculture sectors in both temporary export restrictions and temporary import tariff reductions on such products as wheat, rice, grains, beans, soybeans, sunflower seeds, sugar, onions, garlic, potatoes, carrots, vegetable oil, vegetables, and timber.
Table 5: Reported Information and Communication Technology Capacities for Phytosanitary Certification in CAREC Countries

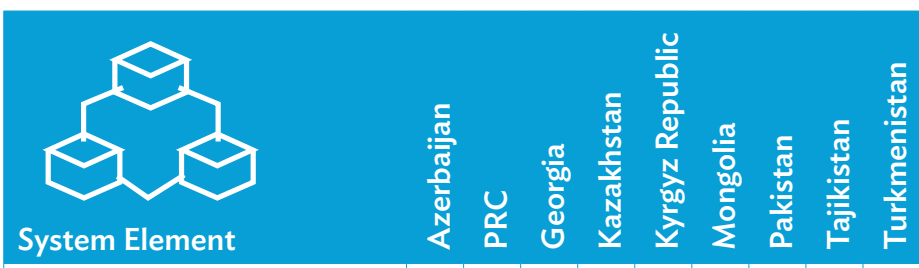

Use of XML message structure for the exchange of electronic certificate data

Use of standardized terms, codes, and text for the data elements associated with the XML message

Data encryption using a secure protocol with minimum of 128 -bit encryption

UN/CEFACT-recommended standard messages

\begin{tabular}{|c|c|c|c|c|c|c|}
\hline & • & & & & & - \\
\hline$*$ & $*$ & $*$ & $*$ & $*$ & $*$ & • \\
\hline & - & & & - & & \\
\hline & - & & & & & - \\
\hline
\end{tabular}

CAREC $=$ Central Asia Regional Economic Cooperation, $I C T=$ information and communication technology, PRC = People's Republic of China,

UN/CEFACT = United Nations Centre for Trade Facilitation and Electronic Business, $\mathrm{XML}$ = extensible markup language.

- ICT capacity is reported as available by the survey respondents or known via other means.

* ICT capacity is reported as partially available by the survey respondents.

Notes: Survey data for Uzbekistan have been excluded as it now integrated into the ePhyto Hub, hence the minimum ICT requirements are assumed. Unknown or no response was received from Afghanistan.

Source: ADB and CAREC Institute survey (as of February 2020).

25 These include the use of the two-letter International Organization for Standardization codes for country names, the IPPC database for the scientific names of plants and pests, IPPC commodity terminology to describe consignments, IPPC harmonized terms for treatment types, and the Codex Alimentarius Commission pesticide index for active ingredients.

26 Examples of secure ICT mechanisms are simple object access protocol, secure or multipurpose internet mail extensions, file transfer protocol, and representative state transfer.

27 ADB. 2015. Mongolia: Regional Upgrades of Sanitary and Phytosanitary Measures for Trade Project. Manila.

28 J. Schmidhuber, J. Pound, and B. Qiao. 2020. COVID-19: Channels of Transmission to Food and Agriculture. Rome: FAO. https://doi.org/10.4060/ca8430en. The FAO estimates that eight CAREC countries are less susceptible relative to other countries to pandemic-related disruptions on the supply side. This reflects their agriculture sector's limited reliance on fixed capital, high worker productivity, and comparatively smaller role played in their exports. Half of the eight countries for which data were available were seen to be highly exposed in terms of agriculture to the pandemic's effects on the demand side. This was due to the relatively large portions held by spending on food in overall expenditures and a high dependence on food imports.

29 International Trade Center. Market Access Map: COVID-19 Temporary Trade Measures. https://macmap.org/covid19. 
The global pandemic response has also included streamlined certification-including e-certification-to ensure speedy entry of essential import products while protecting health and safety. ${ }^{30}$ Official notifications of such actions to the WTO have reported acceptance of compliance certification via electronic means such as scanned documents, e-signatures, and dedicated websites or portals. The Organisation for Economic Co-operation and Development recommended the acceptance of electronic certificates of imports, copies of phytosanitary certificates, and certificates of origins. ${ }^{31}$ CAREC countries also adopted temporary measures to facilitate trade and sustain supply chain continuity. Several countries imposed minimum inspection for clearance of goods and encouraged paperless application and submission of import and export licenses or certificates of origin. ${ }^{32}$

Efforts toward adopting the ePhyto Solution should be sustainable and coordinated with broader trade facilitation initiatives. Given the perishable nature of produce and the growing demand and economic opportunities associated with it, the importance of facilitating trade in plants and plant products through electronic certification of SPS compliance will not diminish even after the pandemic ends. The adoption of trade facilitation measures and paperless transaction have been widely recognized, but progress is slow for some CAREC countries (Table 6).

\section{INCREASING DIGITALIZATION AND READINESS OF CAREC MEMBERS TO ADOPT EPHYTO}

\section{The opportunity and necessity for digitalization is increasing,} and CAREC members are well-placed to adopt ePhyto.

Legislative foundation and capacity exist in almost all CAREC countries to use either of the IPPC's two approaches to begin issuing, receiving, and recognizing ePhytos. Many still need legislation to cover the exchange and international storage of electronic data, but no significant legal reform appears necessary to start exchanging IPPC-standard e-certificates. If countries' paper phytosanitary certificates comply with ISPM 12, their SPS systems can begin using either the IPPC's Hub or GeNS electronic processes. Participating in the ePhyto Solution, whether through the Hub or GeNS, strengthens the capacity of their NPPOs to access the phytosanitary import requirements of their trading partners, evaluate applications at any time making certification faster, and improve their current certification processes.

To ensure smooth transition toward ePhyto certification, a national strategy must be formulated. The strategy may include policy and
Table 6: Paperless and Agriculture-Related Trade Facilitation Measures in CAREC Countries, 2021

\begin{tabular}{|c|c|c|c|c|c|c|c|c|c|c|}
\hline Selected Measures & 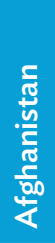 & 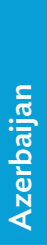 & $\frac{U}{\underline{\alpha}}$ & $\begin{array}{l}\frac{\pi}{50} \\
\frac{0}{8} \\
0\end{array}$ & 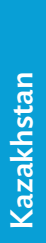 & 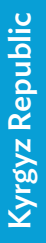 & 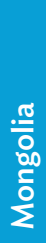 & 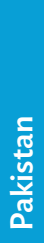 & 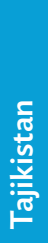 & $\frac{\frac{5}{\pi}}{\frac{n}{\pi}}$ \\
\hline Electronic single window & & • & * & • & * & * & & & $*$ & * \\
\hline $\begin{array}{l}\text { Internet connection } \\
\text { available to customs } \\
\text { and other trade control } \\
\text { agencies }\end{array}$ & & - & $\bullet$ & • & • & - & * & * & - & $\bullet$ \\
\hline $\begin{array}{l}\text { Electronic application } \\
\text { and issuance of import } \\
\text { and export permit }\end{array}$ & & * & * & • & * & $*$ & & $*$ & & $\bullet$ \\
\hline $\begin{array}{l}\text { Testing and laboratory } \\
\text { facilities available to } \\
\text { meet SPS of trading } \\
\text { partners }\end{array}$ & & $\bullet$ & $\bullet$ & * & * & • & $*$ & * & & * \\
\hline
\end{tabular}

CAREC $=$ Central Asia Regional Economic Cooperation, PRC = People's

Republic of China, SPS = sanitary and phytosanitary.

- Measures have been implemented.

* Measures have been partially implemented.

Note: The survey did not cover Turkmenistan. Empty cells mean measures are either not reported or not implemented.

Source: United Nations Global Survey on Digital and Sustainable Trade Facilitation. https://untfsurvey.org/ (accessed July 2021).

regulatory reforms such as on cross-border data exchange and storage; capacity building on certification procedures for NPPOs' technical staff; and multistakeholder dialogue and coordination. CAREC countries must work toward integrating their electronic SPS certification systems with customs and inspection agencies systems through national single window platforms to facilitate border clearances.
Adoption of harmonized and standardized exchange protocols is needed. For now, use of the IPPC's web-based GeNS is the best option for most CAREC members wishing to benefit from the ePhyto Solution. GeNS is simple to set up and use, designed to serve countries that still lack some of the necessary digital systems and capacities to access the Hub directly. The web-based interface works in a low-bandwidth environment and with most devices and browsers. The ePhyto format it provides is machine-readable and standardized to allow internet communication between different computer systems.

30 WTO Secretariat. 2020. Standards, Regulations and COVID-19-What Actions Taken by WTO Members? 20 May. https://www.wto.org/english/tratop_e/ covid19_e/standards_report_e.pdf.

31 Organisation for Economic Co-operation and Development. 2020. OECD Scheme for the Application of International Standards for Fruit and VegetablesPreliminary Report: Evaluation of the Impact of the Coronavirus (COVID-19) on Fruit and Vegetables Trade. 11 May. https://www.oecd.org/agriculture/fruitvegetables/oecd-covid-19-impact-on-fruit-and-vegetables-trade.pdf.

32 CAREC. 2020. Trade Sector Report and Work Plan (September 2019-September 2020). https://www.carecprogram.org/uploads/CAREC-Trade-Sector-Reportand-Workplan.pdf. 
The experiences of the PRC and Uzbekistan could benefit other CAREC countries. The PRC, with a sound functioning SPS e-certification system in place, has long met the technical requirements to exchange ePhytos through the IPPC's Hub. Other CAREC countries with established electronic certification systems could learn from the PRC in terms of achieving system compatibility and more generally, how the inspection and quarantine-related functions were integrated into the PRC's national single window system. Uzbekistan has already begun benefiting from the direct use of the Hub. From the perspective of Uzbekistan's NPPO, automatic communication of the consignment's actual arrival helps prevent fraudulent reuse of certificates to avoid import duties, as well as monitor consignments against potential smuggling and other unauthorized rerouting.

In addition, the ePhyto Solution could be enhanced with a tracking system that can verify ePhyto certificates in transit countriesof particular interest to most landlocked CAREC countries.

It is important to underscore that any digitalization effort must be accompanied by enhanced inspection capacity among NPPOs, in terms of (i) examination of a consignment's documents and verification of their integrity and identity; (ii) pest detection, including sampling and testing, if required; and (iii) application of risk mitigating measures (such as treatment for regulated pests and articles).

\author{
Upgrading, capacity building, and regional cooperation are \\ essential. CAREC members are in a position and encouraged to \\ begin producing, receiving, and exchanging ePhytos to facilitate \\ and expand safe trade in plants and plant products. Moving \\ forward, CAREC countries could consider the following:
}

Analyze the business processes of all involved actors, including readiness to migrate from paper-based certification to the ePhyto system, and the costs and benefits. The WTO's STDF and other development partners provide technical support to strengthen member countries' SPS systems.

Undertake a scoping and/or feasibility assessment to digitalize their respective national certification systems and connect with the ePhyto Hub or GeNS. This assessment will look into the investments required, including onboarding technical requirements, equipment specifications, technical skills and training required to handle digital systems, and reliable internet connectivity especially at the borders.

(iii) Explore interoperability and integration with customs systems and that of other border agencies through the single window platforms.

(iv) Share experience among CAREC countries and consider similar analysis for animals and animal products such as potential expansion of ePhyto Solution to include electronic veterinary certification or e-Vet.

(v) Strengthen stakeholder awareness and management as well as participation by the industry and private sector in the region on the use of electronic certification.
About the Asian Development Bank

ADB is committed to achieving a prosperous, inclusive, resilient, and sustainable Asia and the Pacific, while sustaining its efforts to eradicate extreme poverty. Established in 1966, it is owned by 68 members49 from the region. Its main instruments for helping its developing member countries are policy dialogue, loans, equity investments, guarantees, grants, and technical assistance.

ADB Briefs are based on papers or notes prepared by ADB staff and their resource persons. The series is designed to provide concise, nontechnical accounts of policy issues of topical interest, with a view to facilitating informed debate. The Department of Communications administers the series.

In this publication, “\$” refers to United States dollars.

ADB recognizes "China" as the People's Republic of China.
The views expressed in this publication are those of the authors and do not necessarily reflect the views and policies of ADB or its Board of Governors or the governments they represent. ADB encourages printing or copying information exclusively for personal and noncommercial use with proper acknowledgment of ADB. Users are restricted from reselling, redistributing, or creating derivative works for commercial purposes without the express, written consent of ADB.

Asian Development Bank

6 ADB Avenue, Mandaluyong City

1550 Metro Manila, Philippines

Tel +63286324444

Fax +63286362444

www.adb.org/publications/series/adb-briefs 